\title{
Dengue virus infection in a traveller returning from Croatia to Germany
}

J Schmidt-Chanasit (jonassi@gmx.de) ${ }^{1}$, M Haditsch'2, I Schöneberg ${ }^{3}$, S Günther ${ }^{1}$, K Stark ${ }^{3}$, C Frank ${ }^{3}$

1. Bernhard Nocht Institute for Tropical Medicine, Department of Virology, Hamburg, Germany

2. Labor Hannover MVZ GmbH, Hannover, Germany

3. Robert Koch Institute, Department for Infectious Disease Epidemiology, Berlin, Germany

Citation style for this article:

Schmidt-Chanasit J, Haditsch M, Schöneberg I, Günther S, Stark K, Frank C. Dengue virus infection in a traveller returning from Croatia to Germany. Euro Surveill. 2010;15(40):pii=19677. Available online: http://www.eurosurveillance.org/ViewArticle.aspx?Articleld=19677

Article published on 7 October 2010

Dengue virus (DENV) is endemic in south-east Asia and Central to South America. In August 2010, a DENV infection was diagnosed in a German traveller returning from a trip to Croatia in south-east Europe. The patient presented with fever and other typical symptoms of DENV-infection. Virological investigation revealed the presence of DENV-specific IgM, a rise in DENV-specific IgG and the presence of DENV NS1 antigen in the patient's blood.

Dengue virus (DENV) is an arthropod-borne RNA virus of the Flaviviridae family causing dengue fever in humans. Since 2001 dengue fever has been mandatorily reported to the German public health authorities, in accordance with the Federal Protection against Infection Act [1]. According to German notification data, between 60 and 387 imported DENV infections are reported annually (Table).

The DENV infections in imported cases are mainly acquired in south-east Asia as well as South and Central America. Very recently, autochthonous DENV

\section{TABLE}

Imported cases of dengue fever per year, Germany, $2001-2010^{\mathrm{a}}$

\begin{tabular}{|l|c|}
\hline Year & Number of recorded cases \\
\hline 2001 & 60 \\
\hline 2002 & 213 \\
\hline 2003 & 131 \\
\hline 2004 & 121 \\
\hline 2005 & 144 \\
\hline 2006 & 175 \\
\hline 2007 & 264 \\
\hline 2008 & 273 \\
\hline 2009 & 298 \\
\hline 2010 & 387 \\
\hline
\end{tabular}

Source: Robert Koch Institute, SurvStat

(http://www3.rki.de/SurvStat).

${ }^{a}$ As of 4 October 2010. infections were reported in southern France, diagnosed for the first time ever in Europe [2]. Here we report on a case of DENV infection that was apparently acquired in Croatia and imported to Germany by a traveller.

\section{Case report}

A 72-year-old man from Germany visited Croatia in August 2010: he left on 1 August and returned on 15 August. He was accompanied by seven family members, including grandchildren. The family travelled by car from Germany via Austria and Slovenia to Croatia without overnight stops. The group stayed the entire time around Podobuce close to Orebic on the Peljesac peninsula and on the isle of Korčula in the south of Croatia. Podobuce and Korčula are located approximately $100 \mathrm{~km}$ north-west of the city of Dubrovnik, which was also visited. Temperatures were reported to be very high (approximately $30{ }^{\circ} \mathrm{C}$ at night). After returning to Germany, on 16 August, the patient developed a febrile illness with a temperature of up to $39{ }^{\circ} \mathrm{C}$, chills, arthralgia, headache, and retro-orbital pain. Following a short period of improvement, his temperature rose again to $39{ }^{\circ} \mathrm{C}$ on 21 August, and he continued to have arthralgia, myalgia, weakness and dyspnoea. Among several other diseases, dengue fever was suspected by the general practitioner, because of the clinical picture.

\section{Laboratory results}

Serum samples were taken from the patient for virological investigation on 23 and 30 August and on 2 September. The sample from 23 August was positive for DENV-specific IgM, but negative for IgG in an enzyme-linked immunosorbent assay (ELISA). On 30 August, DENV-specific IgM and IgG was positive with a titre of 1:2,560 (cut-off 1:20) and 1:80 (cut-off 1:20), respectively, in an indirect immunofluorescence assay based on DENV-infected cells. In addition, the serum sample tested positive for DENV NS1 antigen (Dengue Early ELISA, Panbio). Real-time reverse transcriptionpolymerase chain reaction (RT-PCR) for DENV [3] was negative. The detection of DENV NS1 antigen and the simultaneous absence of DENV RNA during this 
phase of dengue fever are in line with previous studies demonstrating an acute DENV infection [4]. The sample taken on 2 September showed an increase in the DENV-specific IgG titre $(1: 1,280)$, while the IgM titre remained unchanged and the ELISA for NS1 antigen was negative. In this sample, immunofluorescence assay titres for related flaviviruses were lower than for DENV: West Nile virus (IgM negative, IgG 1:160) and tick-borne encephalitis virus (IgM 1:80, IgG 1:80). The patient did not report vaccination against tick-born encephalitis or yellow fever. A temporary thrombocytopenia with a minimal platelet count of $97,000 / \mu l$ (norm: $150,000-440,000 / \mu l)$ on the eighth day of the illness resolved without complications and the patient recovered within two weeks after disease onset.

\section{Conclusions}

The clinical suspicion of dengue fever was confirmed by the laboratory tests. As the incubation period for dengue fever ranges from three to 14 days, the infection was probably acquired in southern Croatia and not en route. The Croatian authorities were given all available information about the case, enabling them to investigate this further at local level. To our knowledge, this is the second report on an autochthonous DENV transmission in Europe after France. Antibodies against DENV have been previously detected in Croatian individuals in the context of international travel; however, the specificity of the assay is questionable [5]. The presence of Aedes albopictus as a potential DENV vector in Croatia [6] and the importation of confirmed dengue fever cases from endemic areas into Croatia $[7,8]$ allow autochthonous DENV transmission within this country. The mosquito season in parts of the northern Mediterranean coast may last from May to November. Therefore, dengue fever should be considered in patients with fever of unknown origin and relevant clinical symptoms who stayed in areas in Europe where Ae. albopictus occurs.

\section{Acknowledgements}

We thank M. Reichmann, B. Noack, S. Kunstmann, P. Emmerich, B. Braunsdorf and B. Hiller for preparation of additional clinical, laboratory and epidemiological data related to this case.

References

1. Dreesman J, Benzler J. [Infectious disease surveillance based on the Protection against Infection Act in the German public health sector]. Bundesgesundheitsblatt Gesundheitsforschung Gesundheitsschutz. 2005;48(9):979-89. German

2. La Ruche G, Souarès $Y$, Armengaud A, Peloux-Petiot $F$, Delaunay $P$, Desprès $P$, et al. First two autochthonous dengue virus infections in metropolitan France, September 2010. Euro Surveill. 2010;15(39):pii=19676. Available from: http://www. eurosurveillance.org/ViewArticle.aspx?Articleld=19676

3. Drosten C, Göttig S, Schilling S, Asper M, Panning M, Schmitz $H$, Günther S. Rapid detection and quantification of RNA of Ebola and Marburg viruses, Lassa virus, Crimean-Congo hemorrhagic fever virus, Rift Valley fever virus, dengue virus, and yellow fever virus by real-time reverse transcription-PCR. J Clin Microbiol. 2002;40(7):2323-30.
4. Schilling S, Emmerich P, Günther S, Schmidt-Chanasit J. Dengue and Chikungunya virus co-infection in a German traveller. J Clin Virol. 2009;45(2):163-4.

5. Ropac D, Gould E, Punda V, Vesenjak-Hirjan J. [Dengue viruses in northeastern Croatia]. Lijec Vjesn. 1988;110(6-7):177-80. Croatian.

6. Klobucar A, Merdic E, Benic N, Baklaic Z, Krcmar S. First record of Aedes albopictus in Croatia. J Am Mosq Control Assoc. 2006;22(1):147-8.

7. Markotic A, Betica Radic L, Maretic T. [Viral tourism: dengue virus]. Croatian Journal of Infection. 2007; 27(4):181-4. Croatian.

8. Pinazo MJ, Muñoz J, Betica L, Maretic T, Zekan S, Avsic-Zupanc $\mathrm{T}$, et al. Imported dengue hemorrhagic fever, Europe. Emerg Infect Dis. 2008;14(8):1329-30. 